Evaluating Consistency of Stakeholder Input into Participatory GISBased Multiple Criteria Evaluation: a case study of ecotourism development in Kurdistan

Sarook Sarky ${ }^{*}$, Mary Edwards *, Jim Wright ${ }^{*}$

*Geography and Environment, University of Southampton, Highfield, Southampton, SO17 1BJ, UK

åCorresponding author. Email: sarook.sarky@gmail.com 


\title{
Evaluating Consistency of Stakeholder Input into Participatory GIS- Based Multiple Criteria Evaluation: a case study of ecotourism development in Kurdistan
}

\begin{abstract}
Multiple Criteria Evaluation (MCE) is often used with GIS to identify suitable sites for multi-purpose development such as ecotourism. Typically, expert or stakeholder consultation is used to identify weights reflecting the relative importance of map layers representing different criteria. The objective of this study was to evaluate a new consultative approach to GIS-based MCE, using ecotourism development in Kurdistan, Iraq, as a case study. In an initial and follow-up consultation, stakeholders were asked not only to assess the relative importance of different map layers for ecotourism development, but also to identify specific sites suitable for ecotourism. Seventy-eight ecotourism destinations nominated by participants had significantly higher MCE scores than a set of 58 locations chosen without reference to stakeholders (t-test=21.16; $\mathrm{p}<0.001)$. The approach thus provides a straightforward means of assessing the consistency of stakeholder input into MCE and could be adapted for use in other site suitability assessments.
\end{abstract}

Keywords: ecotourism, GIS, Kurdistan, multiple criteria evaluation, participatory planning

\section{Introduction}

Ecotourism, defined as "responsible travel to natural areas that conserves the environment, sustains the well-being of the local people, and involves interpretation and education" (TIES 2015), has been adopted widely to promote and fund conservation while simultaneously facilitating local community development (Drumm and Moore 2002; Wood 2002; Honey 1999).

Ecotourism development can contribute to post-conflict community rehabilitation and economic reconstruction. For example, after the 1994-98 civil war and genocide in Rwanda, by 2007, tourism industry became the country's highest source of foreign earnings, following a programme of ecological and community-based tourism development (Alluri 2009). Despite its potential, in post-war settings environmental concerns tend to be a low priority, as the planning community must prioritise reconstruction and economic growth (Healey 1997). However, ecotourism 
development has seldom been studied in such settings. Furthermore, participatory approaches to tourism planning face particular challenges where there is little history of participatory governance (Fung and Wright 2003). Autocratic, top-down governance structures may inhibit grassroots collaboration between multiple stakeholder groups, marginalise local communities in the planning process, and centralized power structures may inhibit local decision-making and budgetary responsibility (Altinay et al. 2007; Issa and Altinay 2006; Fletcher 2009; Nianyong and Zhuge 2001).

All of the above conditions are relevant to our study of ecotourism in Kurdistan: the Kurdistan Region of Iraq has been scientifically isolated due to decades of war and political unrest. By means of a workshop, interviews, rapid rural appraisal, and secondary data obtained from different public and private bodies in Kurdistan, we compiled data for Geographic Information System (GIS)-Based MCE analysis. We were also able to reflect on how governance structures and the history of conflict may have affected the outcome of the research.

\subsection{Developing ecotourism in the Kurdistan region}

Although Iraqi Kurdistan is now known for the conflict with Islamic State since late 2014, in the years of stability preceding this conflict, it was regarded as having high potential as a tourist destination because of its rich natural and cultural heritage. Within the region, Jordan successfully marketed its cultural heritage and attracted 1,126 million visitors for tourism and recreation in 2011 (World Tourism Organization 2012). In September 2012, the Arab Council of Tourism elected the city of Erbil in Kurdistan as capital of Arab Tourism for 2014, following a competition with three other nominated cities: Beirut, Taif, and Sharjah (Rudaw 2012). National Geographic Travel editors rated the region in the top 20 places to visit in 2011, describing the region as "an oasis of peace and stability in a historically volatile region” (NEO 2013). According to the General Board of Tourism (GBT), the Kurdistan Region received more than 2.2 million 
tourists in 2012, up 30\% on 2011 (Rwsty 2013b) and from 377,000 visitors in 2007. In 2013, the GBT set a target to attract 4 million visitors in 2015 (Rwsty 2013a).

In April 2012, plans for three ecotourism projects were launched at a workshop organised by the newly established Ecotourism Committee of the GBT. Three sites (see Figure 1), namely the village of Ruste on Halgurd-Sakran Mountain in Erbil, the towns of Halabja in Sulimani and Amedi in Duhok were selected because of their pristine natural environment, unique landscape, traditional community lifestyles, and cultural heritage (Jaleel, Jundi, and Ahmad 2012). Alongside this, given Kurdistan's lack of any designated conservation areas, in 2011 the Kurdistan Regional Government (KRG) began development and gazetting of Halgurd-Sakran National Park, the region's first national park.

\subsection{Participatory GIS and Multiple Criteria Evaluation}

MCE is a multi-dimensional decision-making and evaluation modelling tool that applies trade-offs when selecting between alternatives, such as potential development sites with different environmental and socio-economic impacts (Carver 1991). Locational decisions are reached based on replicable and traceable procedures that draw on a variety of criteria (Lipshitz 1998; Carver and Fritz 1995). The alternatives are ranked according to their attractiveness or suitability for a given objective or purpose based on these criteria. MCE techniques emerged in the early 1970s from a critique of traditional neoclassical economics that called for the incorporation of the environment into economic valuation. MCE was thus developed to better handle the negative effects and environmental externalities of economic development, such as pollution and health risks (Voogd 1983).

In GIS, MCE has mainly been approached either using a Boolean overlay or weighted linear combination approach. In Boolean overlay, areas that are not suitable for development are delineated by dichotomising mappable variables into true/false statements of suitability for the decision under consideration. Such variables are sometimes termed constraints. In comparison, in weighted linear combination, some quantitative criteria are evaluated as continuous variables, thereby depicting varying degrees of suitability for the decision under consideration, and are often referred to as factors (Eastman 1999). MCE techniques have evolved to take into account the 
knowledge or opinions of stakeholders, expert decision-makers (Carver 1991) and/or the general public (Higgs 2006). Typically, these groups identify criteria, select indicators to measure these criteria, and decide on weights reflecting the importance of factors.

\subsection{Multiple Criteria Evaluation and Ecotourism}

GIS and MCE applications have been widely used for tourism (Aminu 2007; Beedasy and Whyatt 1999; Yianna and Poulicos 2002) and ecotourism planning (Bello-Pineda, Ponce-Hernández, and Liceaga-Correa 2006; Fung and Wong 2007; Ghahroudi Tali et al. 2012; Van der Merwe and Van Niekerk 2013).

although MCE has been proposed as a participatory planning tool (Higgs 2006; Bello-Pineda, Ponce-Hernández, and Liceaga-Correa 2006; Zhao and Lin 2002; Jakariya and Bhattacharya 2007; Kumari, Behera, and Tewari 2010; Bukenya 2012), in practice few of these studies consulted with stakeholders over tourism development. For example, Fung and Wong (2007) use their own knowledge rather than consulting others in applying MCE to ecotourism development in Hong Kong, as do many other MCE-based studies of tourism development (Aminu, Matori, and Yusof 2014; Bunruamkaew and Murayam 2011; Kumari, Behera, and Tewari 2010). Thus, although iterative consultation with stakeholders is considered important at all stages of the planning process (Pettit and Pullar 1999), it is rare that any form of consultation takes place in this literature.

A key issue in MCE is whether those consulted provide rational and logically coherent input when assessing suitability criteria. Consistency of stakeholder responses is commonly assessed via the Analytical Hierarchy Process (AHP), in which experts or stakeholders evaluate the relative importance of criteria on a pairwise basis (Saaty 1990; Chandio et al. 2013). Where more than two criteria are involved, a consistency ratio can be calculated from these pairwise ratings. However, the AHP has been criticised because its pairwise ranking approach reduces transparency when those consulted are allocating weights to criteria (Hajkowicz, McDonald, and Smith 2000).

Given that most locational problems involve multiple stakeholders, a second issue is how to combine input from different consultation panel members or arrive at a consensus view. GIS tools, through MCE, can be used to interactively rank different options based on votes by different stakeholders, displaying areas of conflict and 
consensus to develop a final plan (Andrienko, Andrienko, and Jankowski 2003; Jankowski, Zielinska, and Swobodzinski 2008; Boroushaki and Malczewski 2010). Despite the potential of such participatory decision-making approaches, no ecotourismbased studies were identified that used votes by disparate stakeholders or otherwise developed a consensus plan within a GIS-MCE framework.

The main objectives of this study are, therefore, to:

(1) Identify and prioritise potential ecotourism sites using GIS and MCE in post conflict settings.

(2) Evaluate the utility of MCE as a tool for consensus planning and identifying differences between stakeholders.

In addressing these objectives, the study explores the value of iterative consultation with stakeholders. It also develops an alternative approach to the AHP for assessing consistency of stakeholder input and examines the potential use of gravity models as an alternative to distances to nearest features as input criteria.

\section{Data and Methodology}

\subsection{Study Area}

The Iraqi Kurdistan Region (Figure 1) has a population of about 4.5 million within the governorates of Erbil, Duhok, and Sulaimani as well as in small areas of Nineveh, Diyala and Kirkuk Governorates. The Kurdistan region became semi-autonomous in 1991 after the Kurdish uprising against Saddam Hussain’s regime, and a northern no-fly zone was established following the First Gulf War. In 2005, after the Second Gulf War, the Kurdistan Region was declared a federal entity of Iraq via a new constitution. This allowed the region de facto to administer its own affairs independently from national government but still as an integral part of a united Iraq.

Kurdistan's infrastructure was developed following autonomy in 2003, with the subsequent opening of international airports in Erbil and Sulaimani in 2005 (KRG 2013a), and a third international airport in Duhok is planned for 2016 (KRG 2013b). Being more politically stable in comparison to the rest of Iraq, the Kurdistan region is still undergoing political changes, potentially changing what has been historically an 
autocratic approach to decision-making. It therefore differs from places where most other participatory planning research has taken place, such as Canada (Simmons 1994) and Nicaragua (de los Angeles Somarriba-Chang and Gunnarsdotter 2012), both of which have more stable political backgrounds. Furthermore, the political system in both Iraq and the Kurdistan region has had little tradition of participatory democracy, and much of the country's governance is centralised.

\subsection{Methods}

In this study, an iterative approach to stakeholder consultation for GIS-based MCE analysis was adopted. Figure 2 shows the methods used to collect and analyse the data. An initial workshop [February 2012] and a set of semi-structured interviews with stakeholders [March 2012] were used to identify both criteria that defined suitability for ecotourism and specific locations within Kurdistan that might be suitable for development. This informed an initial GIS-based MCE to identify suitable sites for ecotourism development. Following a second consultation two years later [June-July 2014], the GIS-based MCE was revised and the results of the initial and revised MCEs compared.

\subsubsection{Initial Stakeholder Consultation}

A one-day participatory workshop derived from the Ketso ${ }^{\circledR}$ consultation technique (www.ketso.com) was run on 21st February 2012. Ketso is a stakeholder workshop management toolkit designed to facilitate contributions from all attendees, including those who perceive themselves as lower status or their ideas as lacking value (Tippett, Connelly, and How 2011). Participants use coloured cards to record their ideas, with different colours representing goals/next steps, existing assets, future possibilities or solutions, and problems. Participants place cards on different display boards known as 'workspaces', subsequently rearranging the cards so each 'workspace' reflects an emergent theme.

Relevant Kurdish stakeholders, likely to affect or be affected by tourism planning, were invited to this meeting and drawn from academia, government, and the private sector. In total nine delegates participated in the workshop (Table 1). They were asked to identify criteria that indicated a destination's suitability for ecotourism. They also placed cards on a map of the Kurdistan region to choose sites they thought had 
potential for ecotourism. Following the workshop, in March 2012, interviews covering the same issues were conducted with eleven more ecotourism stakeholders identified through snowball sampling via the workshop delegates. In addition, three semistructured interviews were undertaken with key informants from Barzan, Akre and Amedi (a ranger, a shrine-keeper, and a farmer), purposively selected for their particular insights into ecotourism's potential impacts on their communities. These interviews were based on a Rapid Rural Appraisal (RRA) approach (McCracken, Pretty, and Conway 1988), in which local perspectives on rural life are rapidly sought, triangulated against other lines of evidence and evaluated from a multi-disciplinary perspective. These areas were selected for their ecotourism potential, but based on information from contrasting sources: Amedi and Barzan were potential ecotourism destinations discussed in the Ketso-derived workshop whilst Amedi was also proposed as an ecotourism destination by the GBT (Jaleel, Jundi, and Ahmad 2012). Akre was mentioned neither at the workshop nor in the GBT strategic plan, but it was known to be attracting international pilgrims to a well-known shrine, Sheik Abdul Qadir Gailani, and difficulties are arising in accommodating these visitors. In total, 23 stakeholders were interviewed (Table 1).

\subsubsection{Initial Multiple Criteria Evaluation}

Locations of proposed ecotourism sites were digitised and mapped within a GIS. MCE was used to assess site suitability for ecotourism development at these sites through weighted linear combination, with range standardisation of factors.

The criteria identified by stakeholders in this initial workshop and survey were matched against existing spatial data, grouping some concepts listed by stakeholders together under a single indicator where necessary. Relevant map layers (Table 2) were collated within a geospatial database. Although suggested by some participants, distance to accommodation and roads were not included in the MCE analysis because of lack of suitable spatial data. Data sources such as OpenStreetMap (www.openstreetmap.org) and accommodation listings provided by the General Board of Tourism (http://kurdistantour.net/site/maps/) were found to be incomplete and outdated. Distance to the Turkish border, considered by participants to be associated with political insecurity, was also excluded because the subsequent Turkey-Kurdistan Worker Party 
(PKK) peace process, initiated in May 2013 (Christie-Miller 2013), appeared to have resolved the Turkish-Kurdish conflict when the analysis was undertaken.

The potential biodiversity in an area was assessed via a map of 35 Key Biodiversity Areas (KBAs), based on a survey by Nature Iraq (Ararat, Abdul-Hassan, and Abdul-Rahman 2009). KBAs were used because Kurdistan has no gazetted conservation areas. The KBA approach has been widely used internationally to prioritise locations for site-scale conservation. KBAs are themselves identified through the presence of four categories of species: restricted-range species; globally threatened species; congregations of species concentrating at particular sites during specific life cycle stages; and biome-restricted species assemblages (Eken et al. 2004). Although primarily intended for conservation planning, some of the underlying criteria for KBA, notably congregation of wildlife, indicate tourism potential (Shackley 1996). This KBA survey identified both positive qualities (e.g. by-laws restricting hunting/fishing) and threats (e.g. overgrazing; vegetation loss; construction and other development) to each KBA. An attractiveness measure was calculated for each KBA by subtracting the number of threats from the number of positive qualities. A gravity model (Matyas 1997) was then used to estimate the biodiversity potential of each proposed ecotourism site using the following formula:

$$
A_{i=\sum_{1}^{35} M_{j / D i j 2}}
$$

Where $\mathrm{Ai}=$ biodiversity potential for each proposed ecotourism site $\mathrm{i}, \mathrm{Mj}=$ attractiveness for each KBA $\mathrm{j}$, and Dij being the distance between each ecotourism site i and each KBA j.

Cultural heritage attractions were represented via a 1967 map of Iraq's archaeological sites (Table 2), covering sites from all periods from the Neolithic through to the most recent Islamic period (636 A.D. onwards). Rock monuments were distinguished from other archaeological sites and thus handled as a separate criterion.

For all other criteria, Euclidean distances were calculated from each proposed ecotourism site to the nearest of a set of attractions (rivers and lakes), amenities (resorts, accommodation and roads), and hazards (such as landmines and the insecure border with Turkey) using ArcMap 10. Euclidean distance was used instead of drive-times because of a lack of an up-to-date digital roads map layer. To assess the impact of using Euclidean distances, we compared Euclidean distances against drive-times for 78 
trips from proposed ecotourism destinations to the nearest KBA. These drive-times were computed using the Google Maps Application Programming Interface via the ggmap library in the R statistical package (R Development Core Team 2012). In total, seven digital map layers were produced representing these criteria.

Following Eastman (1999), suitability scores S for each site i were thus calculated as:

$$
S_{i}=\sum_{j} w_{j} X_{i j}
$$

Where $w_{j}$ is an importance weight for factor $j$ and $X i j$ represents the standardised score for factor $j$ at site $i$. All factor values were range-standardised to give dimensionless, standardised scores between zero and one:

$$
X_{i j}=\left(x_{i j}-\min _{j}\right) /\left(\max _{j}-\min _{i}\right)
$$

Where $x_{i j}$ is the original value of factor $j$ at site $i, \min _{j}$ is the minimum value of factor $j$ at any site, and $\max _{j}$ is the maximum value of factor $j$ at any site.

Each standardised criterion score was weighted according to the combined number of stakeholder votes it obtained during the Ketso-derived workshop and followup interviews. Weighted criterion scores were then summed to give an overall suitability score for each proposed site.

\subsubsection{Follow-up and Extended Stakeholder Consultation}

In June-July 2014, the 23 participants from the initial workshop and survey were contacted again by phone or Skype and their informed consent obtained to participate in a follow-up study. Seven of the original participants either refused or were unavailable to participate, of whom two provided contact details for replacement participants. It was apparent that the private sector and civil society bodies, typically considered ecotourism stakeholders (Choi and Sirakaya 2006; Eadens et al. 2009), were underrepresented in the referral sample for the initial consultation. The original stakeholder panel was therefore expanded to include a tour operator, an oil industry representative (because of the potential restrictions on other economic sectors resulting from ecotourism development), and a representative of the Religious Endowments civil society body that manages holy sites in Kurdistan.

Participants were then emailed details of ecotourism destination criteria and a map of potential ecotourism sites proposed in the initial consultation or designated by the GBT for development. Interviews were conducted by phone or Skype and 
respondents asked to review the map of ecotourism sites, together with the criteria and map layers used to represent each criterion. An additional criterion 'distance to international airports', not proposed in the initial consultation, was added to the questionnaire, so as to evaluate the appropriateness of the criteria suggested in the initial consultation by assessing whether the participants in the iterative consultation would vote for its retention or removal. This criterion was also added because this seemed a plausible criterion that might have been omitted in the initial consultation (Prideaux 2000). The resultant revised list of criteria were rated by each participant on a 7-point Likert scale ranging from least important [1] to most important [7].

\subsubsection{Follow-up Multiple Criteria Evaluation}

The revised map layers from the follow-up consultation were processed following the same methodology as for the initial MCE, again using weighted linear combination but with two modifications. Firstly, since climate was proposed as a new criterion in the follow-up consultation, the Human Comfort Index (HCI) (Terjung 1968) was used to represent climatic suitability using data for January and July (Table 2). The HCI classifies air temperature and relative humidity into comfort zones, with zone zero being the most comfortable and areas with negative and positive zone numbers being uncomfortably cool or warm respectively. Secondly, instead of weighting criteria according to the number of stakeholder votes as per the initial consultation, criterion weights were based on the mean Likert rating across all participants (Hajkowicz, McDonald, and Smith 2000). Consistency between Likert ratings provided by stakeholders was assessed using the consistency-of-agreement inter-class correlation coefficient (McGraw and Wong 1996) using the Stata software. When a participant suggested the removal of a criterion, it scored zero. As with the initial consultation, some criteria were not included in the GIS-based MCE because no suitable data were available. For example, population density was not included because there has not been a population census of the Kurdistan region since 1997 (GEOHIVE 2014; KRSO 2014). In total, nine digital map layers were produced representing the criteria for the followup MCE analysis. 


\subsubsection{Assessment of Consistency between PESs and Ecotourism Criteria}

To assess consistency between proposed ecotourism destinations and proposed criteria and weightings, MCE-derived scores were calculated using the same criteria for a 'control' set of sites (hotels and motels) in addition to those proposed by the stakeholders. Fifty-eight accommodation locations (hotels and motels), listed by MapCruzin (www.mapcruzin.com), were used as 'controls' in this way. Initial and revised MCE suitability scores for these 58 sites were then compared to those for the ecotourism sites proposed by stakeholders using a t-test for samples with unequal variance in SPSS.

\section{Results}

\subsection{Initial Stakeholder Consultation and MCE}

Table 2 shows the number of votes for criteria proposed during the initial consultation. For example, concepts related to natural and cultural heritage, such as distance to archaeological sites and distance to KBAs, obtained a total of 34 and 22 votes respectively. Conflict-related hazards, such as distance to the Turkish border and distance to landmines, obtained a total of 8 and 6 votes respectively.

Figure 3 shows the attractiveness values for KBAs and the locations of proposed ecotourism sites from the initial consultation. Figure 3 illustrates that in the north of Kurdistan a cluster of PESs, including Amedi, are located very near a group of KBAs including one with the highest mass score. In contrast, PESs outside the Kurdistan region, i.e. Shingar, Tilafar and Tilkef, are far away from the KBAs with Shingar being the farthest.

Figure 4 shows the MCE-derived suitability scores for the 65 proposed destinations. Eight of the 13 most suitable sites are located near Amedi (eight sites) in Duhok province, whilst all three sites located outside the official Kurdistan regional boundary (Shingar, Tilafar, and Tilkef) have low suitability scores. Of the sites proposed by the GBT for ecotourism development Amedi scored highest while Halapja and Ruste scored somewhat lower. 


\subsection{Follow-up Stakeholder Consultation and MCE}

In the follow-up stakeholder consultation, 78 destinations were considered as having potential for ecotourism development. We were able to calculate drive-times for journeys from these destinations to the nearest KBA for 70 of these using the Google Maps API. 6 journeys returned null drive-times via the API and 2 produced implausibly long drive-times. Drive-times for the remainder were moderately correlated with Euclidean distances $(\mathrm{R}=0.75, \mathrm{n}=70)$.

Respondents suggested the removal of 23 of the original 65 PESs from the initial stakeholder consultation, while 36 new, additional PESs were proposed. The PESs proposed in the initial consultation and located within the disputed areas (as seen in Figure 4), namely Tilkef, Tilafar and Shingar, obtained 4, 4 and 2 votes respectively for removal (Figure 6). Sites such as the historic Dalal Bridge in Zakho and the Sarchinar leisure resort in Sulimani were also nominated for removal because of concerns over their heritage value. Meanwhile, sites such as Jerwan, one of the earliest known aqueducts, and Khinis, a series of rock carvings in relief depicting the principal Assyrian gods were suggested by two and three stakeholders respectively as potential ecotourism sites.

All criteria from the initial consultation were retained in the follow-up consultation, with 10 new criteria being proposed (Table 3). Likert scores for most criteria varied among participants, with an individual inter-class correlation coefficient (ICC) of 0.18 (based on 7 criteria and 27 participants; 95\% confidence intervals 0.06 0.55). Given that an ICC of zero indicates no agreement and one indicates complete agreement, this suggests low agreement between stakeholders. The ICC for the average criteria ratings of all stakeholders combined was 0.85 (95\% confidence limits: 0.64 0.97), suggesting that a sample of 27 participants was sufficient to describe the consensus weightings. For the 'landmines' criterion for example, stakeholders' Likert scores ranged from 1 to 7 . Differences are apparent in the magnitude of criteria votes in the initial consultation and average Likert scores from the follow-up consultation. For example, Neo-Assyrian rock-face relief sculptures (NArrs) scored on average 4.2, despite only one participant from the initial consultation proposing this criterion. 22 participants voted for removal of distance to international border (Kurdistan-Turkey). All participants suggested dropping distance to airports, the criterion artificially introduced into the follow-up consultation. 
Furthermore, some of the participants also voted for a threshold effect, but with a wide range of criteria chosen. For example, 16 participants voted for a threshold effect in relation to the existence of transportation, with an average of 8.2 kilometres and a range of 4-15. Also out of 26 participants who suggested NArrs, only 8 voted for its threshold effect, with an average of 8.3 kilometres and a range of 1-20. While some participants suggested thresholds at which criteria became unimportant for ecotourism suitability, these thresholds were, however, not used for the MCE analysis. This was because for most criteria less than half of the participants set a threshold and there was wide variation in the thresholds given by different participants as shown in Table 3.

Figure 5 shows the attractiveness values for KBAs and the locations of proposed ecotourism sites from the follow-up consultation. The figure shows that to the south of Kurdistan three nearby PESs, namely: Awa Spi, Qaradakh and Qopi Qerakh are located within three KBAs, one each, including one KBA with the highest mass score.

Destinations and scores changed considerably between the two MCE phases. A group of highly scoring sites east of Duhok emerged in the follow-up consultation; these, such as Bedul and Khinis (Figure 6), were not apparent from the initial consultation (Figure 4). Conversely, some of the highest scoring sites in the initial MCE such as Sarsink and Ahmadawa (Figure 4) were dropped, while others scored much lower in the follow-up evaluation. Dokan Lake retained its high MCE score during both phases of the MCE analysis. Of the GBT's designated ecotourism destinations, Amedi retained its high MCE score, while Halapja and Ruste scored somewhat lower at follow-up compared to the initial MCE.

\subsection{Assessment of Respondents' Consistency: $\mathrm{MCE}$}

The destinations proposed by the participants, in the initial and follow-up consultations have higher mean MCE scores, of 21.42 and 20.38 respectively, than the 'control' hotels and motels. A t-test shows that scores obtained for the PESs from the initial and revised MCEs were significantly higher than those for the 'control' set of sites $(t=25.53$ and 21.16 respectively; $\mathrm{p}<0.001)$.

Figure 7 and 8 show the MCE suitability scores for the respondents' proposed PESs versus the accommodation units from the initial and follow-up consultations respectively. For example, $86 \%$ of the PESs from the initial consultation $(n=65)$ have suitability scores of over 70 , with the majority in the range $70-80$. In contrast, $80 \%$ of 
the accommodation sites $(n=58)$ have suitability scores of less than 60 with the majority in the range $50-60$ (Figure 7 ). In the follow-up consultation $70 \%$ of the PESs ( $n=78$ ) have suitability scores over 80 with the majority in the range $80-90$. In contrast, $88 \%$ of the accommodation sites have suitability scores of less than 80 with the majority in the range 50-60 (Figure 8).

\section{Discussion}

\subsection{Methodological Issues in MCE implementation}

Unlike most previous MCE-based studies of tourism and ecotourism [e.g. Bello-Pineda et al. (2006) and Proctor and Drechsler (2006)], this study has explicitly documented the process of consultation with stakeholders. None of these earlier studies reported consulting with stakeholders on an iterative basis, nor did they report on the degree of consensus between stakeholders over criteria and weights. Furthermore, while a small number of studies, such as Chandio et al. (2013) and Kumari et al. (2010), have used the Analytical Hierarchy Process to assess the logical consistency of input from stakeholders, the AHP approach has been criticized for making the process of assigning weights unclear to those who are consulted (Hajkowicz, McDonald, and Smith 2000). This study has sought to address these issues by cross-checking specific ecotourism destinations proposed by participants against proposed criteria and their associated weights to see if these were consistent with one another. Ecotourism destinations nominated by participants had consistently higher MCE scores than a set of accommodation (hotels and motels) locations chosen without reference to stakeholders (Sections 2.2.5 and 3.3), suggesting respondents provided logically coherent input to the MCE.

For calculating distance to the nearest of a set of attractions (Kumari, Behera, and Tewari 2010; Bunruamkaew and Murayam 2011), the gravity modelling approach used for the KBAs had two advantages. Firstly, it incorporated attractiveness of KBA sites rather than using only physical distance to the nearest KBA. Secondly, it gave greater consideration to places close to clusters of KBAs compared to those close to a single, isolated KBA (Anderson 2010). This gravity modelling approach could be extended to incorporate other criteria, such as the supply of suitable accommodation (Sharpley 2000). Similarly, although the Terjung $(1968,120)$ comfort index has previously been 
used to analyse climatic suitability for ecotourism, we believe this is the first time it has been used in an MCE-based study.

\subsection{Destinations and their Potential for Ecotourism Development}

Although GIS-based MCE has been used to identify suitable areas for ecotourism in Qesham Island (Dashti et al. 2013) and Miankaleh Peninsula (Ghahroudi Tali et al. 2012) in Iran, this study is the first to plan ecotourism using GIS in Iraq. Since the study took place, market confidence in Kurdistan's tourism sector collapsed following the Islamic State insurgency and capture of the city of Mosul in June 2014 (Anonymous 2015), with a reported 72 hotel closures. Because of this, participants avoided selecting sites from the disputed areas between the Kurdistan region and Iraq, selecting three sites there initially (Shingar, Tilafar and Tilkef) but voting for their removal in the follow-up consultation because of the threat that Islamic State. Despite participants reacting to the unfolding complex emergency in the follow-up consultation phase, with many governments advising against all but essential travel to the region (Foreign Travel Advice 2016), the ecotourism development that this exercise was intended to support therefore stalled as a consequence of the subsequent conflict. In keeping with experience in Lebanon, Burundi and elsewhere (Novelli, Morgan, and Nibigira 2012), this highlights the fragility of tourism as a post-conflict reconstruction strategy.

Of the three sites proposed by the GBT for ecotourism development, Amedi had the highest MCE score and Ruste the lowest during both MCE analysis phases, but despite this the GBT has only approved Ruste for ecotourism development. In a neighbouring valley to Ruste (approximately 12 kilometres away), Hassan Bag Mountain, a potential ecotourism site proposed by participants in the follow-up consultation, obtained a higher MCE score than Ruste.

Whilst there was near-consensus among participants in both consultations in voting for the KBAs, none of the participants proposed rural development criteria relating to remote local communities, such as rural unemployment rates or lack of local services. This reflects the broader observation that local communities are often ignored as stakeholders in the ecotourism industry (Coria and Calfucura 2012; Stronza and Gordillo 2008; Blangy and Mehta 2006; Lu and Bao 2004). In Iran (Zarkesh, Almasi, and Taghizadeh 2011), Uganda (Bukenya 2012) and India (Kumari, Behera, and Tewari 2010) extensive efforts have been made to use MCE to reconcile conflicting stakeholder 
goals when selecting sites for ecotourism development. The approach used here could therefore be adopted by the General Board of Tourism, both to review and expand the existing proposed set of ecotourism destinations.

\subsection{Stakeholder Awareness of Ecotourism and Iterative Consultation}

Since criteria weights were assigned by individuals in the second consultation rather than by consensus as in the initial workshop, different stakeholders varied considerably in the scores they assigned to different criteria in the follow-up consultation, as evidenced by the Likert score ranges in Table 3 and low inter-class correlation for criterion scores from individual stakeholders.

There was substantial disagreement in criteria weights between the initial and follow-up consultations, and in the sites put forward for ecotourism development. Some proposed sites that scored highly initially were subsequently removed in the follow-up consultation, such as Haspa valley, Bare Sile, Sarsink, Ahmadawa, and Inishki. This change may be because stakeholder voting was used to weight factors in the initial consultation, whereas a Likert rating method was used in the follow-up consultation. A second possible explanation is that ecotourism awareness among stakeholders increased by the follow-up phase compared to 2012. Subjectively, this is supported by their elimination of some sites lacking obvious potential for ecotourism development, such as Dalal Bridge in Zakho, and Sarchinar in Sulimani, and the addition of two Neo-Assyrian archaeological sites (Jerwan and Khinis ) built in the 8th - 7th century BC (Bonacossi 2014; Boehmer 1997) that are already attracting international tourists (Traveller 2013). This might indicate that stakeholders' understanding of ecotourism has broadened to include cultural as well as natural heritage (Ayala 1996; Roaf 1996; WMF 2008), either through the iterative participatory consultation process or rapidly increasing engagement with the international community and its ideas.

Since all the participants in the follow-up consultation voted for the removal of distance to airports criterion artificially inserted by the researcher, the stakeholder panel thus successfully rejected a criterion that they themselves had not proposed. 


\subsection{Limitations - MCE implementation under political instability}

Given the relatively recent emergence of an independent regional Kurdish administration, secondary data collection was limited by the absence of a spatial data infrastructure (Rajabifard and Williamson 2001), meaning that government departments had to be approached individually for data, often with limited success. A wider lack of current, appropriate spatial data also affected the study. For example, the neo-Assyrian rock relief locations were based on data from 1967, and, since there has not been a census in Kurdistan since 1997, no demographic data were available. Moreover, neither the natural nor cultural heritage data used here included information about the fragility of the sites, so the attractiveness measure used in gravity modelling of KBAs ignores this issue. In creating a composite index of KBA attractiveness, we assumed that the threats and opportunities at each site were of equal importance. Stakeholder consultation would provide a means of weighting these characteristics to reflect their relative importance and potentially a more realistic attractiveness measure. Furthermore, we used Euclidean distances rather than drive-times to assess proximity between proposed destinations and attractions or hazards such as landmines, potentially impacting on suitability scores. Although Euclidean distances are often highly correlated with drive-times, in the mountainous terrain of Kurdistan the correlation was only modest, confirming the impact of physical barriers reported elsewhere (Boscoe, Henry, and Zdeb 2012).

Furthermore, the Kurdistan region is changing rapidly due to economic growth from oil revenues (Al-Khuzaie 2013) and political stability (relative to the rest of Iraq). Spatial data representing criteria thus become quickly outdated, for example, as road and infra-structure construction is funded by oil revenue. In addition, a wider climate of rapid socio-economic change and political uncertainty means the results of the consultation exercise could rapidly become out of date. The escalating political disagreement between the Kurdistan Regional Government and the Iraqi Central Government and the rapid growth of Islamic State is likely to deter potential investors (Teye 1999), and it reduced international visitor numbers by at least 50\%, according to the GBT. One solution in this situation would be to have regular stakeholder reviews of MCE outputs, but this adds to ecotourism planning costs.

More in-depth initial education of participants could have potentially altered the list of criteria proposed and consequently changed the MCE scores for the final 
suitability maps. Participants in both consultations (Table 2 and Table 3) did not propose criteria used in other studies such as land use/cover; elevation; slope (Bunruamkaew and Murayam 2011); species diversity; or species distribution and conservation status [extinct, critically endangered, endangered, etc.] (Ghahroudi Tali et al. 2012), perhaps because of a lack of awareness of such concepts and/or such data.

Finally, criterion transformations are often neglected in MCE and can also alter site suitability scores (Fung and Wong 2007). Since there were few votes for any threshold effects here, no transformations were applied to input criteria, but this may reflect the difficulty of communicating the complex concept of non-linearity to the stakeholder panel.

\subsection{Future research}

It would be possible to further refine the MCE approach adopted here as an alternative to use of the AHP. For example, in this approach consistency between MCE suitability scores and proposed destinations was assessed based on aggregate weights from the entire group of stakeholders and the set of destinations proposed by all stakeholders. It would be possible to analyse consistency between weights and destinations proposed by individual stakeholders rather than the aggregate recommendations of a group of stakeholders. For example, MCE scores could be calculated based on criteria weightings from a particular stakeholder. Scores could then be compared for sites proposed by that stakeholder versus sites proposed by all other stakeholders consulted.

In future ecotourism suitability assessments, MCE criteria could be broadened as appropriate data become available to include information on ecosystem fragility, cultural heritage value of archaeological sites, and landscape character, as well as amenities such as road networks, access to public services, and accommodation facilities (Bunruamkaew and Murayam 2011). Furthermore, criteria related to local community concerns (Hossain et al. 2009; Tudes and Yigiter 2010) including, for example, high rural unemployment, poor service access, high and rural out-migration, could be used to prioritise ecotourism site selection in MCE. Widening the current national stakeholder consultation to include international tour operators or tourists would enable assessment of market demand for the different ecotourism destinations (Higham and Carr 2002). Given the emphasis on benefit-sharing with local communities in much ecotourism work, an appropriate next step following MCE would 
be to consult with local communities at shortlisted destinations, so as to assess potential socioeconomic benefits such as employment and revenue generation but also potential adverse impacts on the community (Stone and Wall 2004).

\section{Conclusion}

MCE is a potentially valuable tool for ecotourism destination planning because it documents stakeholder or expert judgements concerning different criteria and their impact on the decision-making process. Traditionally, consistency in stakeholder input has been evaluated through the AHP. Here, we have successfully implemented an alternative approach to assessing consistency of stakeholder input by assessing MCE scores for destinations proposed by stakeholders. The approach could be applied to other site suitability selection problems and developed further, for example by comparing destinations and criteria proposed by individual stakeholders. The study also highlighted the potential role for gravity models within MCE.

This study suggests that sites such as Armedi proposed by the GBT are suitable for ecotourism development, but there may be other suitable sites that have been missed. The apparent lack of stakeholder consideration of criteria relating to local community development underlines the need for greater education within the stakeholder consultation process. The lack of justification for decisions made by the central administration (e.g., the choice of Ruste over other, apparently more suitable locations for ecotourism) highlights a need for better communication between government authorities and stakeholders. More generally, the current uncertain political and security environments in Kurdish Iraq raise challenges for MCE-based GIS, given the potential for rapid and unanticipated change. Adoption of techniques such as MCE by the GBT and other Kurdish decision-makers would, however, lead to a more systematic and transparent approach to ecotourism destination planning. 


\section{Acknowledgements}

The authors acknowledge financial support from the Kurdistan Regional Government (KRG), the British Institute for the Study of Iraq and the University of Southampton. The University of Duhok is also acknowledged for giving permission to use one of the university workshop halls. Recognitions are due to Mr Nadr Rwsty and Ms Deedar Jaleel for providing the authors with some useful information and policy documents regarding ecotourism development in Kurdistan issued by the General Board of Tourism - KRG. 


\section{References}

Al-Khuzaie, Khudheir. 2014. "Khudheir Mussa Al-Khuzaie, Vice-President of Iraq, Addresses General Assembly, 68th session, 2013." Crethiplethi, Accessed 02/10. http://www.crethiplethi.com/khudheir-mussa-al-khuzaie-vice-presidentof-iraq-addresses-general-assembly-68th-session-2013/islamic-countries/iraqislamic-countries/2013/.

Alluri, Rina M. 2009. "The role of tourism in post-conflict peacebuilding in Rwanda." Review of.

Altinay, Levent, Turgut Var, Suzette Hines, and Kashif Hussain. 2007. "Barriers to sustainable tourism development in Jamaica." Review of. Tourism Analysis 12 (1-2):1-13.

Aminu, M, A N Matori, and K W Yusof. 2014. "A spatial decision support system (SDSS) for sustainable tourism planning in Cameron Highlands, Malaysia." Review of. IOP Conference Series: Earth and Environmental Science 18 (1):012139.

Aminu, Mansir. 2007. "A geographic information system (GIS) and multi-criteria analysis for sustainable tourism planning." Universiti Teknologi Malaysia, Faculty of Built Environment.

Anderson, James E. 2010. "The gravity model." In.: National Bureau of Economic Research.

Andrienko, Gennady, Natalia Andrienko, and Piotr Jankowski. 2003. "Building Spatial Decision Support Tools for Individuals and Groups." Review of. Journal of Decision Systems 12 (2):193-208. doi: 10.3166/jds.12.193-208.

Anonymous. 2016. "Iraqi Kurdistan tourism in tatters as IS war drags on." news.com.au, Accessed 15/07. http://www.news.com.au/travel/traveladvice/iraqi-kurdistan-tourism-in-tatters-as-is-war-drags-on/newsstory/e44ae04a333ba7986d8e2572eb9a58e5.

Ararat, Korsh, Nabeel Abdul-Hassan, and Saman Abdul-Rahman. 2009. "Key Biodiversity Survey of Kurdistan, Northern Iraq: 2009 Site Review " In 2009 Site Review, 150. Sulaimani, Kurdistan Region, Iraq: Nature Iraq.

Ayala, Hana. 1996. "Resort ecotourism: A paradigm for the 21st century." Review of. The Cornell Hotel and Restaurant Administration Quarterly 37 (5):46-53. doi: http://dx.doi.org/10.1016/0010-8804(96)88974-9.

Beedasy, Jaishree, and Duncan Whyatt. 1999. "Diverting the tourists: a spatial decisionsupport system for tourism planning on a developing island." Review of. International Journal of Applied Earth Observation and Geoinformation 1 (34):163-74. doi: http://dx.doi.org/10.1016/S0303-2434(99)85009-0.

Bello-Pineda, J., R. Ponce-Hernández, and M. A. Liceaga-Correa. 2006. "Incorporating GIS and MCE for Suitability Assessment Modelling of Coral Reef Resources." Review of. Environmental Monitoring and Assessment 114 (1-3):225-56. doi: 10.1007/s10661-006-4628-y.

Blangy, Sylvie, and Hitesh Mehta. 2006. "Ecotourism and ecological restoration." Review of. Journal for Nature Conservation (Jena) 14 (3-4):233-6.

Boehmer, Rainer Michael. 1997. "Bemerkungen bzw. Ergänzungen zu Gerwan, Khinis und Faidhi." Review of. Baghdader Mitteilungen 28:245-9.

Bonacossi, Daniele. 2014. "Back to Assyria: Cities, villages and canals in the Land behind Nineveh." Accessed 02/10. http://asorblog.org/back-to-assyria-citiesvillages-and-canals-in-the-land-behind-nineveh/. 
Boroushaki, Soheil, and Jacek Malczewski. 2010. "Measuring consensus for collaborative decision-making: A GIS-based approach." Review of. Computers, Environment and Urban Systems 34 (4):322-32. doi: http://dx.doi.org/10.1016/j.compenvurbsys.2010.02.006.

Boscoe, Francis P., Kevin A. Henry, and Michael S. Zdeb. 2012. "A Nationwide Comparison of Driving Distance Versus Straight-Line Distance to Hospitals." Review of. The Professional Geographer 64 (2):188-96. doi: 10.1080/00330124.2011.583586.

Bukenya, James Obadiah. 2012. "Application of GIS in ecotourism development decisions: Evidence from the Pearl of Africa." Review of. Research paper:30.

Bunruamkaew, Khwanruthai, and Yuji Murayam. 2011. "Site Suitability Evaluation for Ecotourism Using GIS \&amp; AHP: A Case Study of Surat Thani Province, Thailand." Review of. Procedia - Social and Behavioral Sciences 21 (0):269-78. doi: http://dx.doi.org/10.1016/j.sbspro.2011.07.024.

Carver, Stephen J. 1991. "Integrating multi-criteria evaluation with geographical information systems." Review of. International Journal of Geographical Information Systems 5 (3):321-39. doi: 10.1080/02693799108927858.

Carver, Stephen J., and Steffen Fritz. 1995. "Mapping the wilderness continuum." Review of. Proceedings of the GIS Research UK:15.

Chandio, ImtiazAhmed, AbdNasirB Matori, KhamaruzamanB WanYusof, MirAftabHussain Talpur, Abdul-Lateef Balogun, and DanoUmar Lawal. 2013. "GIS-based analytic hierarchy process as a multicriteria decision analysis instrument: a review." Review of. Arabian Journal of Geosciences 6 (8):305966. doi: 10.1007/s12517-012-0568-8.

Choi, HwanSuk Chris, and Ercan Sirakaya. 2006. "Sustainability indicators for managing community tourism." Review of. Tourism Management 27 (6):127489. doi: http://dx.doi.org/10.1016/j.tourman.2005.05.018.

Christie-Miller, Alexander. 2014. "PKK militants start withdrawal from Turkey, fueling optimism for peace process." Accessed 08/08. http://www.csmonitor.com/World/Europe/2013/0508/PKK-militants-startwithdrawal-from-Turkey-fueling-optimism-for-peace-process.

Coria, J., and E. Calfucura. 2012. "Ecotourism and the development of indigenous communities: The good, the bad, and the ugly." Review of. Ecological Economics 73:47-55. doi: DOI 10.1016/j.ecolecon.2011.10.024.

Dashti, Soolmaz, Seyed Masoud Monavari, Seyed Mohsen Hosseini, Borhan Riazi, and Mansoor Momeni. 2013. "Application of GIS, AHP, Fuzzy and WLC in Island Ecotourism Development (Case study of Qeshm Island, Iran)." Review of. Life Science Journal 10 (1).

de los Angeles Somarriba-Chang, Matilde, and Yvonne Gunnarsdotter. 2012. "Local community participation in ecotourism and conservation issues in two nature reserves in Nicaragua." Review of. Journal of Sustainable Tourism 20 (8):102543. doi: 10.1080/09669582.2012.681786.

Drumm, Andy, and Alan Moore. 2002. "Ecotourism Development: A Manual for Conservation Planners and Managers." In An Introduction to Ecotourism Planning, edited by Alex Singer.

Eadens, L. M., S. K. Jacobson, T. V. Stein, J. J. Confer, L. Gape, and M. Sweeting. 2009. "Stakeholder Mapping for Recreation Planning of a Bahamian National Park." Review of. Society \& Natural Resources 22 (2):111-27. doi: 10.1080/08941920802191696. 
Eastman, JR. 1999. "Multi-criteria evaluation and GIS." Review of. Geographical information systems 1:493-502.

Eken, Güven, Leon Bennun, Thomas M. Brooks, Will Darwall, Lincoln D. C. Fishpool, Matt Foster, David Knox, et al. 2004. "Key Biodiversity Areas as Site Conservation Targets." Review of. Bioscience 54 (12):1110-8. doi: 10.1641/0006-3568(2004)054[1110:kbaasc]2.0.co;2.

Fletcher, Robert. 2009. "Ecotourism discourse: challenging the stakeholders theory." Review of. Journal of Ecotourism 8 (3):269-85. doi: 10.1080/14724040902767245.

Foreign Travel Advice. 2016. "Iraq." GOV.UK, Accessed 15/07. https://www.gov.uk/foreign-travel-advice/iraq.

Fung, Archon, and Erik Olin Wright. 2003. "Thinking about Empowered Participatory Governance Archon Fung and Erik Olin Wright." In Deepening democracy: Institutional innovations in empowered participatory governance, edited by Archon Fung;Erik Olin Wright, 3.

Fung, Tung, and FK-K Wong. 2007. "Ecotourism planning using multiple criteria evaluation with GIS." Review of. Geocarto International 22 (2):87-105.

GEOHIVE. 2014. "General Information." Accessed 25/09. http://www.geohive.com/cntry/iraq.aspx.

Ghahroudi Tali, Manijeh, Seyed Hasan Sadough, Mohammad Ali Nezammahalleh, and Sakineh Khatoon Nezammahalleh. 2012. "Multi-criteria evaluation to select sites for ecotourism facilities: a case study Miankaleh Peninsula." Review of. Anatolia 23 (3):373-94. doi: 10.1080/13032917.2012.712872.

Hajkowicz, Stefan A., Geoff T. McDonald, and Phil N. Smith. 2000. "An Evaluation of Multiple Objective Decision Support Weighting Techniques in Natural Resource Management." Review of. Journal of Environmental Planning and Management 43 (4):505-18. doi: 10.1080/713676575.

Healey, Patsy. 1997. Collaborative planning: shaping places in fragmented societies: UBc Press.

Higgs, Gary. 2006. "Integrating multi-criteria techniques with geographical information systems in waste facility location to enhance public participation." Review of. Waste management \& research 24 (2):105-17.

Higham, James, and Anna Carr. 2002. "Ecotourism Visitor Experiences in Aotearoa/New Zealand: Challenging the Environmental Values of Visitors in Pursuit of Pro-environmental Behaviour." Review of. Journal of Sustainable Tourism 10 (4):277-94. doi: 10.1080/09669580208667168.

Honey, Martha. 1999. Ecotourism and Sustainable Development: Who Owns Paradise? Washington, D.C.: Island Press.

Hossain, M. Shahadat, Sayedur Rahman Chowdhury, Nani Gopal Das, S. M. Sharifuzzaman, and Abida Sultana. 2009. "Integration of GIS and multicriteria decision analysis for urban aquaculture development in Bangladesh." Review of. Landscape and Urban Planning 90 (3-4):119-33. doi: http://dx.doi.org/10.1016/j.landurbplan.2008.10.020.

Issa, Ina Aurelia, and Levent Altinay. 2006. "Impacts of political instability on tourism planning and development: the case of Lebanon." Review of. Tourism Economics 12 (3):361-81. doi: 10.5367/000000006778493664.

Jakariya, M. D., and Prosun Bhattacharya. 2007. "Use of GIS in local level participatory planning for arsenic mitigation: A case study from Matlab Upazila, Bangladesh." Review of. Journal of Environmental Science and Health, Part A 42 (12):1933-44. doi: 10.1080/10934520701567221. 
Jaleel, Deedar, Shireen Jundi, and Bawar Ahmad. 2012. Developing Ecotourism in Kurdistan. Paper presented at the Ecotourism Proposals by the Ecotourism Committee, Erbil, Kurdistan Region of Iraq, 01/04/.

Jankowski, Piotr, Arika-Ligmann Zielinska, and Martin Swobodzinski. 2008. "Choice Modeler: A Web-based Spatial Multiple Criteria Evaluation Tool." Review of. Transactions in GIS 12 (4):541-61. doi: 10.1111/j.1467-9671.2008.01111.x.

KRG. 2013. "Fact Sheet: Travel to the Kurdistan Region in Iraq." Kurdistan Regional Government, Accessed 08/01/2013. http://www.krg.org/p/print.aspx?l=12\&smap=010000\&p=301.

_ . 2013. "Prime Minister hosts groundbreaking for Duhok International Airport." Kurdistan Regional Government, Accessed 02/01/2013. http://www.krg.org/a/d.aspx?l=12\&a=45353.

KRSO. 204. "Surveys." Kurdistan Region Statistics Office, Accessed 20/06. http://www.krso.net/en/surveys.

Kumari, S., M. D. Behera, and H. R. Tewari. 2010. "Identification of potential ecotourism sites in West District, Sikkim using geospatial tools." Review of. Tropical Ecology 51 (1):75-85.

Lipshitz, Gabriel;Massam, Bryan H. 1998. "Classification of development towns in Israel by using multicriteria decision aid techniques." Review of. Environment and Planning A 30 (7):1279-94.

Lu, Xue-mei, and Ji-gang Bao. 2004. "UNRAVELING ECOTOURISM PRACTICE: PROBLEM ANALYSIS BASED ON STAKEHOLDERS." Review of. Chinese Geographical Science 14 (1):82-9.

Matyas, Laszlo. 1997. "Proper Econometric Specification of the Gravity Model." Review of. World Economy 20 (3):363-8. doi: 10.1111/1467-9701.00074.

McCracken, Jennifer A, Jules N Pretty, and Gordon R Conway. 1988. "Introduction to rapid rural appraisal for agricultural development." In Introduction to rapid rural appraisal for agricultural development. International Institute for Environmentand Development.

McGraw, Kenneth O, and Seok P Wong. 1996. "Forming inferences about some intraclass correlation coefficients." Review of. Psychological methods 1 (1):30.

NEO. 2013. "20 Best Trips of 2011." National Geographic, Accessed 22/02/. http://travel.nationalgeographic.com/travel/best-trips-2011-photos\#/15kurdistan-iraq-delal-bridge_30416_600x450.jpg.

Nianyong, Han, and Ren Zhuge. 2001. "Ecotourism in China's Nature Reserves: Opportunities and Challenges." Review of. Journal of Sustainable Tourism 9 (3):228-42. doi: 10.1080/09669580108667400.

Novelli, Marina, Nigel Morgan, and Carmen Nibigira. 2012. "Tourism in a post-conflict situation of fragility." Review of. Annals of Tourism Research 39 (3):1446-69. doi: http://dx.doi.org/10.1016/j.annals.2012.03.003.

Pettit, C., and D. Pullar. 1999. "An integrated planning tool based upon multiple criteria evaluation of spatial information." Review of. Computers, Environment and Urban Systems 23 (5):339-57. doi: http://dx.doi.org/10.1016/S01989715(99)00029-0.

Prideaux, Bruce. 2000. "The role of the transport system in destination development." Review of. Tourism Management 21 (1):53-63. doi: http://dx.doi.org/10.1016/S0261-5177(99)00079-5.

Proctor, W., and M. Drechsler. 2006. "Deliberative multicriteria evaluation." Review of. Environment and Planning C-Government and Policy 24 (2):169-90. doi: $10.1068 / \mathrm{c} 22 \mathrm{~s}$. 
R Development Core Team. 2012. R: A language and environment for statistical computing. Vienna, Austria: R Foundation for Statistical Computing.

Rajabifard, Abbas, and Ian P Williamson. 2001. "Spatial data infrastructures: concept, SDI hierarchy and future directions." Review of.

Roaf, Michael. 1996. Cultural Atlas of Mesopotamia and teh Ancient Near East. Abingdon, Oxfordshire, England: Andromeda Oxford Limited

Rudaw. 2012. "Erbil Named 2014 Arab Tourism Capital." Accessed 30/12/2012. http://www.rudaw.net/english/kurds/5443.html.

Rwsty, Nadir. 2013a. "2015 target to get 4 Million Visitors to the Kurdistan Region of Iraq." In Zarikrmanji. Zarikrmanji.com. . 2013b. "Tourism Figures 2013." In Nadr Rusty. Faceebook.com: General Board of Tourism, Kurdistan Region.

Saaty, Thomas L. 1990. "How to make a decision: The analytic hierarchy process." Review of. European Journal of Operational Research 48 (1):9-26. doi: http://dx.doi.org/10.1016/0377-2217(90)90057-I.

Shackley, Myra L. 1996. Wildlife tourism. London: International Thomson Business Press.

Sharpley, Richard. 2000. "The influence of the accommodation sector on tourism development: lessons from Cyprus." Review of. International Journal of Hospitality Management 19 (3):275-93. doi: http://dx.doi.org/10.1016/S02784319(00)00021-9.

Simmons, David G. 1994. "Community participation in tourism planning." Review of. Tourism Management 15 (2):98-108. doi: http://dx.doi.org/10.1016/02615177(94)90003-5.

Stone, Mike, and Geoffrey Wall. 2004. "Ecotourism and Community Development: Case Studies from Hainan, China." Review of. Environmental Management 33 (1):12-24. doi: 10.1007/s00267-003-3029-z.

Stronza, A., and J. Gordillo. 2008. "Community views of ecotourism." Review of. Annals of Tourism Research 35 (2):448-68. doi: DOI 10.1016/j.annals.2008.01.002.

Terjung, W. H. 1968. "World patterns of the distribution of the monthly comfort index." Review of. International Journal of Biometeorology 12 (2):119-51. doi: 10.1007/bf01553502.

Teye, Victor B. 1999. "Commentary: Tourism plans and planning challenges in Ghana." Review of. Tourism Geographies 1 (3):283-92. doi: 10.1080/14616689908721322.

TIES. 2015. "What is Ecotourism." The International Ecotourism Society, Accessed 03/10. http://www.ecotourism.org/what-is-ecotourism.

Tippett, Joanne, Angela Connelly, and Fraser How. 2011. "You Want Me to Do What? Teach a Studio Class to Seventy Students?" Review of. Journal for Education in the Built Environment 6 (2):26-53. doi: 10.11120/jebe.2011.06020026.

Traveller, The. 2013. "Iraqi Kurdistan - Land of Kurds." The Traveller, Accessed 05/07/. http://www.thetraveller.co.uk/The\%20Middle\%20East/Iraq/Iraqi\%20Kurdistan\%20\%20Land\%20of\%20the\%20Kurds-15.

Tudes, Sule, and NazanDuygu Yigiter. 2010. "Preparation of land use planning model using GIS based on AHP: case study Adana-Turkey." Review of. Bulletin of Engineering Geology and the Environment 69 (2):235-45. doi: 10.1007/s10064009-0247-5. 
Van der Merwe, Johannes H, and Adriaan Van Niekerk. 2013. "Application of geospatial technology for gap analysis in tourism planning for the Western Cape." Review of. South African Journal of Science 109 (3-4):1-10.

Voogd, Henk. 1983. Multicriteria evaluation for urban and regional planning: Pion London.

WMF. 2014. "Cultural Heritage Sites of Iraq." World Monuments Fund, Accessed 05/10. http://www.wmf.org/project/cultural-heritage-sites-iraq.

Wood, Megan. 2002. Ecotourism: Principles, Practices and Policies for Sustainability. Paris Cedex, France: United Nations Environment Programme.

World Tourism Organization. 2012. Compendium of Tourism Statistics, Data 20062010, 2012 Edition, Compendium of Tourism Statistics, Data 2006-2010, 2012 Edition. Madrid: UNWTO.

Yianna, Farsari, and Prastacos Poulicos. 2002. "GIS Contribution for the Evaluation and Planning of Tourism: a sustainable tourism perspective." Review of. web: http://www. gipsynoise.(jobs and economic growth), as w ell as tourism positive influence on quality of life. This study emphasizes previous research findings. Additionally, the study findings provide a glimpse of residents.

Zarkesh, Mir Masoud Kheikhah, Nahid Almasi, and Farzad Taghizadeh. 2011. "Ecotourism land capability evaluation using spatial multi criteria evaluation." Review of. Res J Appl Sci Eng Technol 3 (7):693-700.

Zhao, Yibin, and Hui Lin. 2002. Participatory decision-making for ecological planning. Paper presented at the Web Information Systems Engineering Workshops, International Conference on. 


\section{Tables}

Table 1. Characteristics of stakeholders consulted in a participatory workshop and follow-up interviews

\begin{tabular}{|c|c|c|c|c|c|c|}
\hline \multirow{2}{*}{\multicolumn{3}{|c|}{ Sector }} & \multicolumn{2}{|c|}{ Initial consultation } & \multicolumn{2}{|c|}{$\begin{array}{c}\text { Follow-up } \\
\text { consultation }\end{array}$} \\
\hline & & & Workshop & Interviews & Iterative & New \\
\hline 1 & \multirow{4}{*}{ 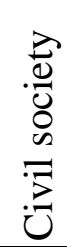 } & \multirow{2}{*}{\begin{tabular}{|l} 
Environmental NGO \\
Warar Development \& Growth Org. \\
\end{tabular}} & & 1 & \multicolumn{2}{|l|}{1} \\
\hline 2 & & & & 1 & \multicolumn{2}{|l|}{1} \\
\hline 3 & & \multicolumn{3}{|l|}{ Religious (local clerk) } & & 1 \\
\hline 4 & & Local community & & 3 & 1 & \\
\hline 5 & \multirow{5}{*}{ 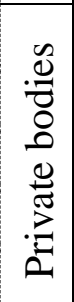 } & Local tour operator & & 2 & 1 & \\
\hline 6 & & International tour operator & & & & 1 \\
\hline 7 & & Accommodation (Hotel) & & & & 1 \\
\hline 8 & & Oil Extractor & & & & 1 \\
\hline 9 & & Vendor* & & & & 1 \\
\hline 10 & & Environmental Protection Forces & 1 & & 1 & \\
\hline 11 & & General Directorate of Environment & 2 & & 1 & \\
\hline 12 & & General Directorate of Tourism & 2 & & 1 & \\
\hline 13 & & Institute of Planning & & 1 & 1 & \\
\hline 14 & & General Board of Tourism & & 1 & & 1 \\
\hline 15 & & General Board of Investment & & 1 & 1 & \\
\hline 16 & & Duhok Governorate & & 1 & 1 & \\
\hline 17 & & General Directorate of Municipalities & & 1 & & 1 \\
\hline 18 & & Directory of Archaeology & & 1 & 1 & \\
\hline 19 & & National Security Forces & & & & 1 \\
\hline 20 & \multirow{3}{*}{ 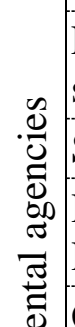 } & $\begin{array}{l}\text { Forestry and wildlife Research } \\
\text { service }\end{array}$ & & & & 1 \\
\hline 21 & & Social welfare services & & & & 1 \\
\hline 22 & & $\begin{array}{l}\text { Health care sector (Ministry of } \\
\text { Health) }\end{array}$ & & & & 1 \\
\hline 23 & \multirow{3}{*}{$\begin{array}{l}\bar{\Xi} \\
\text { 泀 } \\
0 \\
0 \\
0\end{array}$} & General Board of Statistics & & & & 1 \\
\hline 24 & & $\begin{array}{l}\text { Education sector (Ministry of } \\
\text { Education) }\end{array}$ & & & & 1 \\
\hline 25 & & Geology Department & & & & 1 \\
\hline 26 & \multicolumn{2}{|c|}{ Academia (universities) } & 4 & 1 & 1 & 1 \\
\hline
\end{tabular}

* A shopkeeper of a wholesaler group who directly provides goods to tourists amenities, e.g. hotels 
Table 2. Criteria for GIS-based Multiple Criteria Evaluation (MCE) from the initial consultation

\begin{tabular}{|c|c|c|c|c|}
\hline \multirow[t]{2}{*}{ Criteria } & \multirow[t]{2}{*}{ Data set } & \multicolumn{3}{|c|}{$\begin{array}{c}\text { No. of votes (weight) } / 23 \\
\text { participants ( } 9 \text { Workshop }+11 \\
\text { Interviews }+3 \text { Local } \\
\text { community) } \\
\end{array}$} \\
\hline & & Workshop & Interview & Total \\
\hline $\begin{array}{l}\text { Distance to } \\
\text { Archaeological sites }\end{array}$ & $\begin{array}{l}\text { Directorate General of Antiquities } \\
\text { (1967): 1:1,500,000 scale } \\
\text { Archaeological Map of Iraq. } \\
\text { Baghdad, Republic of Iraq } \\
\text { (http://www.wdl.org/en/item/212/). }\end{array}$ & 12 & 22 & 34 \\
\hline $\begin{array}{l}\text { Distance to Key } \\
\text { Biodiversity Areas }\end{array}$ & $\begin{array}{l}\text { Nature Iraq report on key } \\
\text { biodiversity areas (Ararat, Abdul- } \\
\text { Hassan, and Abdul-Rahman 2009) }\end{array}$ & 3 & 19 & 22 \\
\hline $\begin{array}{l}\text { Distance to Natural } \\
\text { Attractions (Resorts) }\end{array}$ & $\begin{array}{l}\text { General Board of Tourism in Erbil } \\
\text { (http://bot.gov.krd/map). }\end{array}$ & 4 & 7 & 12 \\
\hline Distance to Rivers & $\begin{array}{l}\text { Directorate of Geological Surveys } \\
\text { in Erbil digital topographic } \\
\text { database, } 2012\end{array}$ & 4 & 6 & 10 \\
\hline Distance to Lakes & $\begin{array}{l}\text { Directorate of Geological Surveys } \\
\text { in Erbil: digital topographic } \\
\text { database, } 2012 \text {. }\end{array}$ & 5 & 5 & 10 \\
\hline $\begin{array}{l}\text { Distance to } \\
\text { International Border } \\
\text { (Kurdistan-Turkey)* }\end{array}$ & $\begin{array}{l}\text { Global Administrative Boundaries } \\
\text { database, version } 2.8 \\
\text { (http://www.gadm.org/) }\end{array}$ & 1 & 7 & 8 \\
\hline $\begin{array}{l}\text { Distance to } \\
\text { Landmines }\end{array}$ & $\begin{array}{l}\text { Iraqi Kurdistan Mine Action } \\
\text { Agency, Erbil (2012): 1:1,000,000 } \\
\text { scale map of hazardous areas, } \\
\text { Duhok, Eribl, Sulimani and } \\
\text { Garmian }\end{array}$ & 3 & 3 & 6 \\
\hline $\begin{array}{l}\text { Distance to } \\
\text { Accommodation* }\end{array}$ & $\begin{array}{l}\text { General Board of Tourism in Erbil } \\
\text { (http://bot.gov.krd/map). }\end{array}$ & 0 & 4 & 4 \\
\hline Distance to Roads* & $\begin{array}{l}\text { Directorate of Geological Surveys } \\
\text { in Erbil: digital topographic } \\
\text { database, } 2012\end{array}$ & 0 & 3 & 3 \\
\hline $\begin{array}{l}\text { Distance to Neo- } \\
\text { Assyrian Rock } \\
\text { Reliefs }\end{array}$ & $\begin{array}{l}\text { Directorate General of Antiquities } \\
\text { (1967): 1:1,500,000 scale } \\
\text { Archaeological Map of Iraq. } \\
\text { Baghdad, Republic of Iraq } \\
\text { (http://www.wdl.org/en/item/212/). }\end{array}$ & 0 & 1 & 1 \\
\hline
\end{tabular}

* The criteria were not used due to lack of suitable spatial data or subsequent political events 
Table 3. Criteria for GIS-based MCE from follow-up consultation

\begin{tabular}{|c|c|c|c|c|c|c|c|c|}
\hline \multirow[t]{2}{*}{ Criteria } & \multirow[t]{2}{*}{ Data use } & \multirow{2}{*}{$\begin{array}{l}\text { No. of } \\
\text { voters }\end{array}$} & \multicolumn{2}{|c|}{$\begin{array}{l}\text { Likert score } \\
(1-7)\end{array}$} & \multirow{2}{*}{$\begin{array}{l}\text { Votes for } \\
\text { removal } \\
(n=27)\end{array}$} & \multirow{2}{*}{$\begin{array}{l}\text { Votes for } \\
\text { threshold } \\
\text { effect }\end{array}$} & \multicolumn{2}{|c|}{$\begin{array}{l}\text { Threshold } \\
\text { level }(\mathrm{km})\end{array}$} \\
\hline & & & Average & Range & & & Average & Range \\
\hline 1 Dist. to $\mathrm{KBAs}^{(1)}$ & $\begin{array}{l}\text { Initial \& } \\
\text { Follow up }\end{array}$ & 27 & 6 & $3-7$ & 0 & 10 & 6.5 & $1-15$ \\
\hline 2 Dist. to landmines ${ }^{(1)}$ & $\begin{array}{l}\text { Initial \& } \\
\text { Follow up }\end{array}$ & 27 & 6 & $1-7$ & 0 & 15 & 5.9 & $1-40$ \\
\hline $\begin{array}{l}\text { Dist. to Archaeological } \\
\text { sites }^{(1)}\end{array}$ & $\begin{array}{l}\text { Initial \& } \\
\text { Follow up }\end{array}$ & 27 & 5.9 & $2-7$ & 0 & 11 & 7.2 & $1-20$ \\
\hline $\begin{array}{ll}4 & \text { Dist. to Natural } \\
& \text { Attractions } \\
& (1)\end{array}$ & $\begin{array}{l}\text { Initial \& } \\
\text { Follow up }\end{array}$ & 27 & 5.6 & $4-7$ & 0 & 13 & 11 & $3-25$ \\
\hline 5 Dist. to lakes ${ }^{(1)}$ & $\begin{array}{l}\text { Initial \& } \\
\text { Follow up }\end{array}$ & 27 & 5.1 & $2-7$ & 0 & 11 & 11 & $1-35$ \\
\hline $6 \begin{array}{l}\text { Dist. to Religious } \\
\text { sites }^{(2)}\end{array}$ & Follow up & 27 & 4.8 & $3-7$ & 0 & 5 & 9.2 & $1-30$ \\
\hline 7 Dist. to Police points & $\begin{array}{l}\text { No data } \\
\text { available }\end{array}$ & 27 & 5.8 & $4-7$ & 0 & 13 & 10.6 & $3-15$ \\
\hline 8 Dist. to Roads & $\begin{array}{l}\text { No data } \\
\text { available }\end{array}$ & 27 & 5.5 & $4-7$ & 0 & 12 & 3.9 & $1-10$ \\
\hline $\begin{array}{ll}9 & \text { Dist. to } \\
& \text { Accommodation }\end{array}$ & $\begin{array}{l}\text { No data } \\
\text { available }\end{array}$ & 27 & 5.4 & $1-7$ & 0 & 16 & 13 & $8-20$ \\
\hline 10 Dist. to Public services & $\begin{array}{l}\text { No data } \\
\text { available }\end{array}$ & 27 & 5 & $3-6$ & 0 & 8 & 9.1 & $5-20$ \\
\hline 11 Dist. to Nature reserves & $\begin{array}{l}\text { No data } \\
\text { available }\end{array}$ & 27 & 4.8 & $2-7$ & 0 & 8 & 21 & $\begin{array}{l}10- \\
30\end{array}$ \\
\hline 12 Dist. to Health services & $\begin{array}{l}\text { No data } \\
\text { available }\end{array}$ & 27 & 4.8 & $3-7$ & 0 & 18 & 11.1 & $5-35$ \\
\hline $\begin{array}{l}13 \text { Dist. to Tourism } \\
\text { viewpoints }\end{array}$ & $\begin{array}{l}\text { No data } \\
\text { available }\end{array}$ & 27 & 4.7 & $2-7$ & 0 & 7 & 12 & $5-30$ \\
\hline 14 Dist. to Rivers & $\begin{array}{l}\text { Initial \& } \\
\text { Follow up }\end{array}$ & 26 & 5.2 & $0-7$ & 1 & 12 & 7.2 & $1-20$ \\
\hline 15 Dist. to NArrs ${ }^{(1)}$ & $\begin{array}{l}\text { Initial \& } \\
\text { Follow up }\end{array}$ & 26 & 4.2 & $0-7$ & 1 & 8 & 8.3 & $1-20$ \\
\hline 16 Climatic factors $^{(3)}$ & Follow up & 24 & 3.8 & $0-5$ & 3 & n/a & $\mathrm{n} / \mathrm{a}$ & $\mathrm{n} / \mathrm{a}$ \\
\hline $\begin{array}{l}17 \text { Existence of } \\
\text { Transportation }\end{array}$ & $\begin{array}{l}\text { No data } \\
\text { available }\end{array}$ & 24 & 6.1 & $4-7$ & 0 & 16 & 8.2 & $4-15$ \\
\hline $\begin{array}{l}18 \text { Dist. to Population } \\
\text { density }\end{array}$ & $\begin{array}{l}\text { No data } \\
\text { available }\end{array}$ & 21 & 3.9 & $3-7$ & 6 & 8 & 23.3 & $\begin{array}{l}10- \\
50\end{array}$ \\
\hline 19 Dist. to Worship places & $\begin{array}{l}\text { No data } \\
\text { available }\end{array}$ & 20 & 2.4 & $0-5$ & 7 & 11 & 11 & $7-15$ \\
\hline $20 \begin{array}{l}\text { Dist. to Int. Border } \\
\text { (Kurdistan-Turkey) }\end{array}$ & $\begin{array}{l}\text { Criterion } \\
\text { not used }\end{array}$ & 5 & 2.4 & $0-7$ & 22 & 4 & 12.5 & $5-20$ \\
\hline 21 Dist. to Airports & $\mathrm{n} / \mathrm{a}$ & 0 & 0 & & 27 & 0 & $\mathrm{n} / \mathrm{a}$ & $\mathrm{n} / \mathrm{a}$ \\
\hline
\end{tabular}

(1) For dataset refer to Table 2

(2) Dataset: GBT website (http://kurdistantour.net/site/maps/)

(3) Dataset: WorldClim, average air temperature data for 1950-2000 (http://www.worldclim.org/tiles.php).

OpenEI, average relative humidity data for July 1983 - June 2005

(http://en.openei.org/datasets/taxonomy/term/543) 


\section{Figure Captions}

Figure 1. Sites within the Kurdistan Region of Iraq proposed for ecotourism development by the General Board of Tourism

Figure 2. Flowchart of methodology for identifying suitable ecotourism sites in the Kurdistan region of Iraq

Figure 3. Attractiveness index values for Kurdistan Biodiversity Areas (KBAs), as used to calculate potential natural heritage value using a gravity model for each potential ecotourism site (PES) for the initial consultation

Figure 4. Potential ecotourism destinations and their MCE scores from the initial consultation (higher scores indicate greater suitability)

Figure 5: Attractiveness index values for Kurdistan Biodiversity Areas (KBAs), as used to calculate potential natural heritage value using a gravity model for each potential ecotourism site for the follow-up consultation

Figure 6: Revised potential ecotourism destinations and their MCE scores from the follow-up consultation

Figure 7. Frequency of different suitability (MCE) scores between PESs proposed by stakeholder in the initial consultation and sites selected by the researcher (accommodation units).

Figure 8: Frequency of different suitability (MCE) scores between PESs proposed by stakeholder in the follow-up consultation and sites selected by the researcher (accommodation units). 